\title{
The German Occupation of Cluj - Kolozsvár and its Consequences on the History of the City in 1944
}

\section{Kristóf János MURÁDIN}

\author{
Departamentul de Ştiințe Juridice şi Studii Europene, Facultatea de Ştiințe şi Arte, Cluj-Napoca, \\ Universitatea Sapientia \\ Jogtudományi és Európai Tanulmányok Tanszék, Természettudományi és Művészeti Kar, Kolozsvár, \\ Sapientia Erdélyi Magyar Tudományegyetem \\ Department of Juridical Sciences and European Studies, Faculty of Sciences and Arts, \\ Sapientia Hungarian University of Transylvania \\ Calea Turzii 4, 400193 Cluj-Napoca, jud. Cluj, Romania \\ muradinjanoskristof@yahoo.com
}

The main objectives of this study are on the one hand to create a clear image of the German occupation of Kolozsvár ${ }^{1}$ in 1944, and on the other hand to realize an analysis of exact consequences of this particular historical event upon the life of population of the city, and especially upon the Jewish community. The topicality of the theme is given by the $70^{\text {th }}$ anniversary of the occupation in spring 2014.

Beside important scientific publications which interpreted this period, during my researches I used several scientific articles, as well as the local contemporary press. By completing the obtained data with those selected from some interviews made with persons who were eye-witnesses to the events in case, I tried to bring some new aspects to this theme.

In order to understand the exact reasons of the German occupation, first we have to take a look on the historical preludes and describe the contemporary circumstances under which it happened. After the First World War, according to the peace treaty of Trianon signed on 4 June 1920, Hungary lost two-thirds of its territory. Not taking into consideration traditionally autonomous Croatia, the territory of Hungary shrank from 282 thousand $\mathrm{km}^{2}$ to 93 thousand $\mathrm{km}^{2}$. The largest area that was lost was Transylvania, containing more than 103 thousand $\mathrm{km}^{2}$, which, together with its five million inhabitants, was attached to Romania. ${ }^{2}$ In Transylvania, many nationalities had been living side by side for centuries: Romanians, Hungarians, Germans, Jews, Ruthenians (Transcarpathian Ukrainians), Gypsies and Slovaks. However, both the Romanians and the Hungarians, which were the most numerous of all the nationalities, cherished it as the place where their states had been born. Therefore, Hungary did not want to give up its rights to it forever, while Romania was ready to acquire it by all means. This explains the fact that Transylvania became the main target of Hungary's revisionist policy. Thus "Great Romania," created in 1918-1920 as a result of the advantageous political conditions, confronted the idea of "a thousand-year old Hungarian state." In 1919, Romanian troops invaded eastern Hungary and even occupied Budapest in an effort to bring under Romanian control as much territory as possible to enhance the nation's

\footnotetext{
1 Nowadays, the official name of the city in Romanian language is Cluj-Napoca. In this study the author uses the Hungarian name Kolozsvár, which was the official name in the early 1940s.
}

2 Ignác ROMSICS, Magyarország története a XX. században, Budapest 2003, 147. 
bargaining position. But soon they were withdrawn from the territory of Hungary, and in the twenties the relationship between the two states became somewhat less tense. However, beginning from the mid-1930s, Hungary returned to its policy based on the demand of total revision. This was made possible by the rise of national-socialist Germany which officially supported all kinds of revisionist claims. ${ }^{3}$

The Second World War created a new situation. The main enemy of Germany was the Soviet Union, and in order to be able to attack it successfully, the Germans wanted peace in the Balkans and South-Eastern Europe. Hitler wanted to avoid any possibility of a Hungarian-Romanian "private war". Therefore, he was ready to promise many things both to Miklós Horthy, the regent of Hungary, and to General (later Marshal) Ion Antonescu, the political leader of Romania. Both of the politicians competed for Hitler's benevolence, and although this was a completely hopeless goal, Hitler managed to make their dependence more final by forcing the signing of the Second Vienna Award on 30 August 1940. ${ }^{4}$

The new borderline made up between the two countries according to the decision of a German-Italian committee in Vienna further increased the tension in the region. Both Hungary and Romania considered the Vienna Award only temporary and, trusting the promises that were generously given by Hitler, they hoped that their claims would be satisfied in the future. Therefore, they remained loyal to the Führer. ${ }^{5}$

According to the Second Vienna Award, the northern part of Transylvania $43,104 \mathrm{~km}^{2}$ from the total territory of $103,093 \mathrm{~km}^{2}$ ) was given back to Hungary. ${ }^{6}$ The borderline which divided Transylvania was meant to serve political and economic interests rather than ethnic ones. It is true that the Hungarians were in majority on the territory which was given back, but at the same time, almost the same number of Romanians became a minority. According to the 1941 census by the Hungarian authorities, 1,380 thousand Hungarians and 1,057 thousand Romanians lived in Northern Transylvania. ${ }^{7}$ At the same time, about half a million Hungarians lived in Southern Transylvania which remained a part of Romania.

The new border could not bring permanent peace, and the general atmosphere also proved that the population was not satisfied. The many who became minorities on both sides of the border were in fact "miserable shipwrecked people," although both the Hungarian and the Romanian political leaders proclaimed that they were "warriors" who fought their difficult but noble fight surrounded by deadly enemies. The majority of politicians, officers, and clerks who were sent from Hungary, and whom the local people ridiculed by calling them "parachutists," were full of irredentist slogans. They did not know Transylvania and with their total ignorance of the characteristics of the Transylvanian situation, they made the bad relationship between the two nationalities even worse. In the same way Romanian nationalists took revenge for losing Northern Transylvania with atrocities against the local Hungarian population in Southern Transylvania. These resulted in a massive transfer of populations from the both sides of Transylvania which began in the autumn of 1940, and 3 ROMSICS, 247-249.

4 The First Vienna Award, which gave back the southern part of Slovakia to Hungary, was signed almost two years before, on 2 November 1938.

5 On this issue see Dániel CSATÁRI, Forgószélben. Magyar-román viszony 1940-1945, Budapest 1968, 87-118.

6 Lajos THIRRING, A visszacsatolt keleti terület. Terület és népesség, in: Magyar Statisztikai Szemle, $1940,663$.

7 Balázs ABLONCZY, A visszatért Erdély 1940-1944, Budapest 2011, 47. 
continued until the end of 1944. It stopped only when the Red Army attacked Northern Transylvania. ${ }^{8}$

Shortly after the defeating of German troops by the Red Army in the battle of Stalingrad, by the beginning of 1943 the Hungarian politicians realized that the Germans would lose the war and they tried to make a separate peace with the western Allies. This resulted in the German invasion of the country in March 1944. In the early morning of 19 March 1944 the troops of the Wehrmacht started the occupation of Hungary. This military operation got the name of MARGARETHE I. The arrival of the German troops in Transylvania further increased the suffering of the people in the multicultural region. Only the end of the war brought a change for the better in this respect, but also temporary.

The military act of the occupation created a unique situation: a Great Power engaged in war occupied its ally! Units of the German army invaded every strategic territory of Hungary in just a few days. On 27 March 1944 they entered the city of Kolozsvár. ${ }^{9}$

The OKW (Oberkommando der Wehrmacht) planned to invade Romania too, immediately after they had reestablished calm in Hungary. The plan of a German invasion in Romania called MARGARETHE II, had been drafted by 26 January 1944, and in this operation, the units of the Wehrmacht were to be joined by Hungarian and Bulgarian troops. But Hitler changed his mind about the occupation of Romania, after Marshal Antonescu visited him at his headquarters between 26 and 28 February 1944, when the Romanian leader assured the Führer about his unconditioned loyalty. ${ }^{10}$ In any case, in this final period of the World War Hitler lacked enough military force to occupy Hungary and Romania at the same time. ${ }^{11}$ On 15 March, Hitler called Miklós Horthy for an audience in Klessheim, a castle near Salzburg, Austria, then part of the Third Reich. The regent of Hungary arrived on 18 March. He consented to the German occupation of Hungary under pressure. The German leader made it clear that if Horthy had not agreed, the Wehrmacht's occupying divisions would be joined in the operation by Romanian, Croatian, and Slovak military units. Hitler promised that if Horthy agreed with the Führer's plan to invade the country, the Romanian troops from the southern borderland of Northern Transylvania would be used in the war against the Soviet Union. In this way the possibility of a direct Hungarian-Romanian clash would be reduced considerably. In April 1944, Hitler really kept his promise. ${ }^{12}$

By the same day (18 March) in which Horthy arrived at Hitler's headquarters, eight German divisions - more than 100 thousand troops - were concentrated at the Hungarian borders ready to invade the country. This proved that the Führer had decided to occupy Hungary before asking Horthy, with or without the regent's agreement. The commander of the occupation forces was Field Marshal Maximilian baron von Weichs, who had previously been the commander of the Army Group F, all the German troops in the Balkans being under his command. His headquarters was in Belgrade. He was transferred from there to Vienna at the beginning of March. ${ }^{13}$

\section{CSATÁRI, 44.}

9 György GAAL, Kolozsvár kétezer esztendeje dátumokban, Kolozsvár 2001, 44.

10 Gyula VARGYAI, Magyarország a második világháborúban, Budapest 2001, 309.

11 Ibidem, 315.

12 CSATÁRI, 350-351.

13 Péter GOSZTONYI, A magyar honvédség a második világháborúban, Budapest 1995, 132. 
The beginning of MARGARETHE I was postponed five times. The first scheduled date was 30 September 1943, but it was put off to 28 February next year, after that to 7 March, then to 15 March. Finally, the occupation started on 19 March 1944. ${ }^{14}$ The official order - which was given to the troops of Wehrmacht on 12 March - justified the invasion as "necessary to prevent treason." 15

In the early morning of 19 March 1944, at 4 o'clock, most of the German occupation forces crossed the Hungarian border. The troops formed four attacking columns that came from different directions. One force of three divisions and auxiliary troops entered the country from Belgrade and Újvidék (today called Novi Sad) to the southeast. This massive column included the $92^{\text {nd }}$ Grenadierregiment, the $4^{\text {th }}$ "Brandenburg" Regiment, the $5^{\text {th }}$ SS Polizeiregiment, the $202^{\text {nd }}$ Panzerdivision, the $201^{\text {st }}$ SS Grenadier Brigade, $42^{\text {nd }}$ Jägerdivision, and the $8^{\text {th }}$ SS Reiterdivision, all belonging to the XXII Army Corps. The second invading group contained three divisions advancing from Zagreb in the southwest. These were the $1^{\text {st }}$ Gebirgsjägerdivision, the $367^{\text {th }}$ Infanteriedivision, and the $18^{\text {th }}$ SS Panzergrenadierdivision, all of LXIX Corps. Two more divisions, the $16^{\text {th }}$ SS Panzergrenadierdivision, minus some units still engaged in combat in Italy, and the Panzerdivision "Wiking", both of the LVIII Corps, entered the country from the direction of Vienna, and finally from the northeast came the motorized Grossdeutschland Regiment, the $103^{\text {rd }}$ Feldhernhalle Grenadierregiment, and some smaller units, along with the LXXVIII Army Corps command group. ${ }^{16}$

Budapest was occupied quickly by the Germans on 20 March, and in the evening of the same day Field Marshal von Weichs arrived at the capital. ${ }^{17}$ The occupation of Hungary was fast and totally successful. It was over after only five days, on 24 March. Horthy ordered the Hungarian army to let the German troops enter the country without any resistence. The Hungarian garrison at Újvidék failed to receive the order, so on 19 March there was one encounter with the German army. It was very short and without decisive consequences. ${ }^{18}$ When Lieutenant-General Lajos dálnoki Veress, the commander of the IX. Hungarian Army corps, with its headquarters in Kolozsvár, learned that the occupation had been underway, he ordered the mobilization of the troops under his command on 20 March. He did not know that Horthy had ordered the army not to resist the Germans. But there was no encounter with the Wehrmacht in this region because the German troops entered Kolozsvár only on 27 March. By that time, the rest of the country had already fallen into their hands, and it was futile to fight against them. ${ }^{19}$

The almost bloodless success of the German military action was possible because Horthy had agreed with the occupation, and because the majority of the Hungarian senior officers had traditionally good relations with the German army command. Even more, some of the Hungarian army commanders considered that the German occupation would at last silence pro-western allied sentiment in the country. That is why the troops of Wehrmacht moved

14 VARGYAI, 306.

15 Ibidem, 311.

16 György RÁNKI, Unternehmen Margarethe: Die deutsche Besetzung Ungarns, Budapest 1984, 131.

17 Péter GOSZTONYI, Légiveszély, Budapest! Szemelvények Magyarország második világháborús történetéből (1939-1945), Budapest 1989, 106.

18 Ibidem, 106.

19 GOSZTONYI, 1995, 135. 
totally undisturbed into Hungary. The soldiers were not afraid of any attempt against them. The local population showed a friendly behaviour in front of the Germans everywhere. As a German soldier nostalgically recalled after more than 30 years: "Dies war eigentlich unser letzter Blumenkrieg." (After all, this was our last "flower strewn war") 20 Because of the surprising success of the occupation, some units of the Wehrmacht left Hungary very soon. These engaged in the war against the Soviet Army, which started a devastating attack in the middle of the Eastern front in the last days of March. In this way, the $367^{\text {th }}$ Infanteriedivision and the $100^{\text {th }}$ Jägerdivision were sent to Tarnopol, Ukraine, only 125 miles from the border with Northern Transylvania on 24 March, right after the end of the occupation of Hungary. ${ }^{21}$

Immediately after the occupation, the German ambassador in Hungary, Edmund Veesenmayer, was named to be in "charge of the Empire" (Generalbevolhnächtigter), and Field Marshal Hans von Greiffenberg, the German military attaché in Hungary, became "the commander in charge of all the German Wehrmacht in Hungary", with all the German troops engaged in the operation under his command. ${ }^{22}$

As the front neared the eastern part of Hungary (within Northern Transylvania) and the Szeklerland, a military zone was proclaimed by a ministerial act. It included: Ung, Bereg and Ugocsa counties; the city of Ungvár (today Uzshorod in Ukraine) in northeast Hungary; Bihar, Szatmár, Szilágy, Máramaros, Beszterce-Naszód, Szolnok-Doboka, Kolozs, Maros-Torda, Csík, Háromszék and Udvarhely counties; and the cities of Kolozsvár and Marosvásárhely (today, the official Romanian name of the city is Târgu-Mureş) in Northern Transylvania. By a German order, the commissioner of the military zone in the province called Carpatho-Ukraine became Vilmos Pál Tomcsányi, while Béla ricsói Uhlarik, head of a ministry department, was appointed commissioner of the Transylvanian military zone. ${ }^{23}$ The German army commander of the entire military zone in Eastern Hungary and Northern Transylvania became General Kuno-Hans von Both, the commander of the $16^{\text {th }}$ SS Panzergrenadierdivision. ${ }^{24}$

As the German occupation was approaching a successful end, Marshal Antonescu, the Romanian leader, offered some Romanian divisions to Hitler in order to help the Wehrmacht in invading Hungary. But Hitler knew that if Romanian troops entered Hungary, the Hungarian army would no longer cooperate with the occupying forces and that a Hungarian-Romanian "private war" in Northern Transylvania might follow. Hitler wanted peace and order in this part of Europe, because he knew that the enormous Red Army planned to start a new attack all over the Eastern Front in the early summer of 1944. In order to prevent a Romanian invasion in Northern Transylvania, the OKW decided to occupy Northern Transylvania clear to the Carpathians. Following a direct order from Berlin, the $16^{\text {th }} \mathrm{SS}$ Panzergrenadierdivision crossed the river Tisza at Szolnok on 25 March, entered Northern Transylvania, and marched forward to the Hungarian-Romanian borderline in the centre of

20 Interview with K. T. former German under officer, Stuttgart 1980, in: GOSZTONYI, 1995, 138.

21 RÁNKI, 182.

22 GOSZTONYI, 1995, 209.

23 Keleti Újság, 1944, Year 27, No. 84, 15 April.

24 Ignác ÖRVENDI, Magyarország német megszállása, Budapest 1993, 181. 
Transylvania. Units of this division entered the city of Kolozsvár too on 27 March 1944. ${ }^{25}$ As a consequence of the German invasion of Hungary, the government led by Miklós Kállay had to resign. ${ }^{26}$ The new prime minister, Döme Sztójay, served the Germans unconditionally. From a policy standpoint, he had no experience concerning the governing process of a country. ${ }^{27}$ His extreme right-wing government, in which only the fascist "Nyilaskeresztes Party" did not get a place, and whose rule lasted only for five months, can be considered a puppet government of the Germans. ${ }^{28}$ In addition to the prime minister, the Ministry of the Interior led by Andor Jaross was the political center for carrying out German interests. According to Jaross's opinion, the German entry into the country started "the total and perfect liquidation of Hungarian Marxism and its connected parts" in Hungary. His undersecretaries of state, László Endre and László Baky, shared Jaross's opinion. ${ }^{29}$ They organized an extensive dragnet, arresting people throughout the country. They jailed political personalities and military officers too. Granting the Germans' request, Colonel-General János Vörös became the new commander of the general staff of the Hungarian army, exerting a strong influence on the decisions of Lajos Csatay, the minister of national defence. At Colonel-General Vörös's urging, the $1^{\text {st }}$ Hungarian Army with 180 thousand soldiers was sent out to the Eastern Front, to support the military efforts of the Wehrmacht. With this act, the number of the Hungarian soldiers, fighting at the Eastern edges of the Carpathians increased to 300 thousand. ${ }^{30}$

Béla ricsói Uhlarik relieved a number of county executives and chiefs of the public administration of their posts, especially those who were somehow compromised by their engagement in the liberal politics of the government led by Kállay. ${ }^{31}$ But a great number of political leaders and administrators in Northern Transylvania abandoned their function voluntarily or at least sought to do so. Thus, for example count Béla Bethlen, the chief executive of Szolnok-Doboka and Beszterce-Naszód counties, tried to resign his function, but his resignation was refused by the Ministry of the Interior. ${ }^{32}$ Because of the German invasion, there were changes in the staffs of administration and in the armed force command of Kolozs county and of Kolozsvár city too. Top administrative and military officers were assumed by appointees with anti-Semitic feelings who served German interests unconditionally.

The citizens of Cluj received the news of the German invasion of the country with indignation and fear. Efforts of the official press to present the event as a war necessity in accordance with the wishes of the Hungarian government were unsuccessful. The 23 March 1944 issue of Ellenzék, a daily paper in Kolozsvár, claimed that the German troops arrived in Hungary in order to support the Hungarians in the war against the common enemy and

25 Percy Ernst SCHRAMM, Kriegstagebuch des Oberkommando des Wehrmacht (Wehrmachtführungsstab) 1940-1945, vol. 4, Frankfurt am Main 1965, 625-629.

26 Miklós KÁLLAY, Magyarország miniszterelnöke voltam 1942-1944, vol. 2, Budapest 2012, $202-209$.

27 Mária ORMOS, Magyarország a két világháború korában (1914-1945), Debrecen 1998, 257.

28 ROMSICS, 260.

29 VARGYAI, 325.

30 ORMOS, 258.

31 CSATÁRI, 353.

32 Béla BETHLEN, Észak-Erdély kormánybiztosa voltam, Budapest 1989, 135. 
especially to support their efforts in defeating Bolshevism. ${ }^{33}$ Ellenzék, and generally the entire official press, tried to conceal the disagreement between the German and the Hungarian political and military commands, and it did not criticize the fact of the German invasion. In the same way, the local Romanian press, especially the daily Tribuna Ardealului, declared that the German occupation was the consequence of an agreement between the German and the Hungarian governments. This paper confined its reporting to an exact communication of the events and published only the official German explanation of the invasion of Hungary: "In the interest of the fight against Bolshevism and in the common interest of the European associated countries of the Axis Powers, German troops entered Hungary." (This followed the German DNB news agency's report.) ${ }^{34}$ In general, the Hungarian and the Romanian press of Kolozsvár published the fact of the German occupation just four to five days after its start, combined with the establishment of the Sztójay government and its inspiring declaration to the population.

The city of Kolozsvár confronted the German occupation directly for the first time on 27 March 1944, when the first train, with its elegant Habsburg-era dining room, carrying Wehrmacht units arrived at the railway station. Soon German tanks were occupying their firing positions under the trees of the Central Park. At the same time, preparing to defend against air attack, the Germans installed some anti-aircraft cannons in the southern Roundhill quarter of the city and on the strategic heights known as the Citadel, just north of the Kis-Szamos (Someşul Mic - Little Samos) River.

Ferenc László, a citizen of Kolozsvár remembered the German occupation of the city as follows: "On Sunday, 19 March the German occupation of the country started. At that time, I was in the third class of school, I was only 14 years old. The day after the beginning of the invasion even we, the children, were discussing in the school what can come after this. The war preoccupied very much even the youth. We had been following the situation of the front on our maps since 1939, using coloured pins. We were marking the places heard on the radio in 1944 too, paying attention with anxiety to the approaching of the war by the Germans' 'systematic evacuations'.

After the entry of the German troops to Kolozsvár on 27 March 1944, we went on holiday at the early date of 31 March because all the schools were closed. Later, at the beginning of May, almost every school was transformed into a military hospital. In the day of the occupation, German soldiers were walking on the streets, and sometimes were asking at bigger houses for a spare room for them. Usually the people let them in with pleasure. We also accomodated in our house seven of them.

I can say about the German soldiers that they had a very civilized behaviour, because they knew that we were allies, not enemies. They were very disciplined soldiers. They were present at the social and the sport events, and they even played football with the locals.

In that time, Kolozsvár was still far from the line of the Eastern Front. Because of this, there weren't a great number of German soldiers in the city. In spite of this, the trees of the Central Park sheltered a lot of tanks, cannons, and trucks. The promenades of the Park were full of German armored cars, and on the top of the Citadel there were settled some units

33 Ellenzék, 1944, Year 65, No. 67, 23 March.

34 Tribuna Ardealului, 1944, Year 5, No. 1004, 25 March. 
of German anti-aircraft artillery." 35

Another inhabitant of Kolozsvár, Márton Varga remembered the events of March 1944 in the following way: "In that time we were living in the western part of the city. Because of this, I had to cross the Central Park every evening when I went home. I remember that after the German occupation, the Park was full of trucks belonging to the Wehrmacht. Among them there were some tanks too. They were sheltered against the bombardments under the big trees of the Park. There was not a showy German invasion in Kolozsvár; in fact their military units just entered the city sporadically." 36

The population of Northern Transylvania did not offer considerable resistence against the Germans. The Hungarian nation was grateful to the Germans, because they considered Trianon a national catastrophe, and because of the very effective Nazi propaganda which caused widespread fear of Bolshevism in the main part of the society. They looked at the Wehrmacht as the only effective power, able to stop Communism. ${ }^{37}$

About the feelings of the population caused by the German occupation Béla Bethlen at that time governor of two counties of Northern Transylvania, wrote in his memoir the following: "[...] the Germans invaded the country early in the morning of 19 March. The occupying operation was so quick and it took place with so much power, that in fact there wasn't any impressive resistance. The whole population of the country was surprised and shaken by the event, although it could have been expected." 38 Although a lot of people were disillusioned by the German alliance, instead of futile resistance, they accommodated to the changed conditions. Between the Germans and the local population there developed a kind of peaceful co-existence.

Initially, the occupation improved the economic situation. The people of Northern Transylvania, who had experienced a serious shortage of goods, started to buy cloth, typewriters, objects of military equipment, and other things from the well-equipped German force. This phenomenon became so general, that it had to be prohibited through a regulation by the Hungarian commissioner of the military zone of Northern Transylvania. ${ }^{39}$

On the other hand, the German occupation complicated the internal political situation of Northern Transylvania. The Magyar Megújulás Pártja (Hungarian Renewal Party) - an extreme right wing party led by Béla Imrédy, which had its bases in the territories remaining under Hungarian rule after 1918 - immediately took advantage of the political vacuum created by the German invasion. It focused on putting all local organizations under the influence of the extreme right wing. It unsuccessfully tried to do the same with the Erdélyi Párt (Transylvanian Party), which was the most important local political group created by the Transylvanian aristocracy in late 1940. Although, the Erdélyi Párt was under considerable political pressure in March 1944, it managed to remain independent of the coalition of the extreme right wing. ${ }^{40}$

35 Ferenc László, interview by author, tape recording, Kolozsvár, 11 November 2003.

36 Márton Varga, interview by author, tape recording, Kolozsvár, 10 November 2003.

37 ROMSICS, 263.

38 BETHLEN, 134-135.

39 Keleti Újság, 1944, Year 27, No. 118, 26 May.

40 Kristóf János MURÁDIN, Összmagyar gondolat regionális köntösben. Az Erdélyi Párt története 1940 és 1944 között, in: Trianoni Szemle, 5, 2013, 1-2, 79. 
The Gestapo settled in at the same time as the German regular troops and established its headquarters in Kolozsvár in the Hotel "New York" (now the "Continental") situated in the heart of the city. Soon it transfered its residence into the "Peter and Paul" villa on the Apáczai Csere János street in the uptown, eastern portion of Kolozsvár. The Gestapo started to register and hunt for well-known Transylvanian Communist sympathizers, and during the month of April interned them with the efficient support of the Hungarian administration. A storm of arrests swept over the whole territory of the country. Between five hundred and one thousand men were taken to the concentration camp in Nagykanizsa, a small town in southwest Hungary, or to concentration and labor camps in the Third Reich. ${ }^{41}$ The arrests in Kolozsvár reached their peak on 15 April 1944 with a mass arrest. The detained persons were accused of sympathizing with Communism, and allegations of support of the partisans also served more and more frequently as justification for using violence. Some of the imprisoned persons were set free, but they remained continuously under the surveillance of the police and were not allowed to leave their homes at all.

After the invasion, in addition to arrests of the well-known left wing sympathizers, the Germans began to compile the lists of the Jewish population of the entire territory of Hungary, relying on phone books and, in some cases, informers. Following the direct order of Adolf Eichmann, the SD Obersturmbannführer, the Sztójay-government gathered most of the Jews in ghettos, and soon a large part of them were deported.

Beginning on 15 May 1944, Hungarian Jews were systematically deported from the eastern parts of the country, first of all to Auschwitz, but also to the death camps of Dachau and Mauthausen, where the most of them died. ${ }^{42}$ Carpatho-Ukraine was the first province from which the entire Jewish population was carried away - almost 200 thousand people -, and after that the deportation under German control started in Northern Transylvania too. The process of taking away the Jews was executed by the Hungarian administration. ${ }^{43}$ In May 1944, 131,641 members of the Jewish population of Northern Transylvania were deported to Auschwitz. By this terrible act the province officially became "judenrein" ("free from Jews"). ${ }^{44}$

Only a few, who suspected the terrible consequences of this deportation, tried to escape by running away to Romanian-held Southern Transylvania. In Kolozsvár, a city on the borderland this seemed to be the best way to avoid deportation, but most of the Jews who tried to escape this way were captured by frontier guards right at the border. Those who managed to pass the heavily patrolled border and reached Torda (today the official name of the city in Romanian language is Turda), escaped. But the number of those who were so lucky was insignificant. Later, after the war, there were several debates on the number of those who escaped and the roles of some of the community's leaders involved in these

41 CSATÁRI, 352. Almost all of those who were arrested survived the war.

42 ORMOS, 259.

43 VARGYAI, 329-330.

44 VARGYAI, 97. 
actions. $^{45}$

The greater part of the Christian population of Kolozsvár watched the collection of the Jews in ghettos passively. Even those who had good relations with the Jews presumed only rarely to show their indignation. Sándor Dózsa, a citizen of Kolozsvár, remembered the dragging of the Jews into ghettos as follows: "In our house there was a Jewish doctor whose name was Szénási and the Weiss family who were also Jewish. I don't know what happened with Doctor Szénási, but I was present at the transportation of the Weiss family into the ghetto. It was a day in spring, when some people arrived on behalf of the authorities to take the Weiss family into the ghetto. I just arrived home. The entire family, an old lady and her two daughters, were pushed on a pallet of a truck, which had transported rubbish before. One of the neighbors helped the old lady in climbing on the pallet. The old lady thanked him. Our neighbor answered with pity: "God save me of getting such thanks in the future..." The people regretted what happened with the Jews. It was totally unpleasant (sic!). The women were crying out on the street when Mrs. Weiss was taken away. We couldn't do anything against this. They were taken by policemen who were coming after them by names and by exact addresses." 46

There were also people who were engaged in talking in the streets or were intentionally walking by, taking the hands of their Jewish friends who wore the yellow star. Some of the people tried to hide the Jews, or to save them from deportation with real or false papers, or even by using their own identity card. Still others preserved the Jewish wealth entrusted to them. But a lot of people immediately presented claims on the expropriated Jewish shops, workshops and on the sealed houses of the Jews that now remained empty. They carried away the objects of value and the clothes of the deported Jews.

Some doctors did behave humanely to the Jews. In the Haynal-, Miskolczy- and Klimkó hospitals in Kolozsvár they hid a lot of Jewish patients under false names. Some other Jews were admitted into private homes. ${ }^{47}$

Most of the population of Kolozsvár watched with indignation and was terrified by the way the Jews were treated. This was the opinion of Márton Varga too, who remembered the events as follows: "It was a real catastrophe. We regretted the destiny of the Jews. They were as much human beings as we were. We had also friends among them. We had no problems living beside them. It is a real fact that they were doing every possible thing to help the poor people.

In our street there weren't Jews, generally the western uptown of the city did not have a

45 Concerning these facts and the debates over the ambiguous role of Moshe Carmilly Weinberger, Ernő Hátszegi, and Ernő Marton see the followings: Randolph L. BRAHAM, A magyar Holocaust, vol. 2, Budapest 1988, 263-269, 274-275; Arnold David FINKELSTEIN, Fénysugár a borzalmak éjszakáján, Tel Aviv 1958, 294, 302-323, 400; Béla VÁGÓ, Political and Diplomatic Activities for the Rescue of the Jews of Northern Transylvania, in: Yad Vashem Studies 6, 1967, 155. Some of the sources speak about 40 thousand Jews escaping from Northern Transylvania to Romania. The most widely accepted figure, however, is 1,500 Jews, based on documents from 1944 (BRAHAM, 263.). For the spirit of auditur et altera pars, see: Raoul ŞORBAN, Remember. 40 de ani de la masacrarea evreilor din Ardealul de Nord sub ocupația horthystă, Bucharest 1985, 44-50; Moshe Carmilly WEINBERGER, A zsidóság története Erdélyben (1623-1944), Budapest 1995, 302-303, 306-309. This escape route, named the "Road of Life", became the subject of a Romanian documentary film in the early 1990s that also does not solve the controversy: "Drumul Vieții," made by Manase Radnev for Televiziunea Română, 1992.

46 Sándor Dózsa, interview by author, tape recording, Kolozsvár, 6 November 2003.

47 Dániel LŐWY, A téglagyártól a tehervonatig. Kolozsvár zsidó lakosságának története, Kolozsvár 1998, 10-11. 
Jewish population. Still I was present when they were gathered in the Széchenyi Square, because I was a shop-assistant in a nearby shop in which accessories of shoes were sold. The Jews were gathered into groups, then they were arranged into rows. Gendarmes and soldiers took care that none of them would have the possibility to escape. The Jews were extremely terrified. They didn't know at all what would happen to them. Although there were a lot of terrible rumors about the destiny of the Jews, they didn't pay attention to them, because they couldn't imagine that something like that would happen to them.

In those times in downtown, at the intersection of the Hosszú- and the Eötvös streets was one of the Jewish schools of the city. Here, there were guided all the Jews from the Széchenyi Square, babies as much as old people. From that school all of them were taken to the ghetto created in the brick-works. Only Hungarian gendarmes and civilians accompanied them, the Germans didn't; they left the whole base procedure to the Hungarians. Among the Jews there were some acquaintances of mine too. We waved to each other. But the guards didn't let us talk. Not a single word was allowed..." 48

The journalist Ferenc László had this to say about the deportation of the Jews of Kolozsvár: "My best friend, Hári Lebovics was a Jew. We were of the same age. We were schoolfellows and neighbors too. They were living at the corner of the streets Rákóczi and Töhötöm, and they had a small grocery shop until it was taken from them by the authorities. They helped the people in a lot of cases; it was possible to buy from them on credit. They were taken too. We never saw each other again. Neither he nor his mother came home from Auschwitz.

I never forget that once, walking on the Malom street I was eye-witness to the taking away of a Jewish family. An old man and a little girl were pushed up into the bed of a truck where there were already some people. Some of them were sitting on a wooden bench, the others were just standing. They were collected from the same house, because there were living only Jews. On the breast of the old man next to the yellow star I recognized some Hungarian military decorations from the First World War. There was the troop star of King Charles, the little silver- and the bronze grades of the Heroism Medal and the Signum Laudis too. The little girl had a doll in her hands. She was pressing it into her little breast even when the truck was starting to move with them. Her mother was sitting beside her. It was a very mournful scene. I was terribly sorry for them.

Most of the Jews were taken away at night, so there would not be eye-witnesses to the action. If my memory serves me well, the time was announced when the policemen and the soldiers would come to a street to take the Jewish families away. At that time all the members of the family had to be at home. Hungarian gendarmes, members of the Hungarian military police and German soldiers accompanied the transports of the Jews to the ghetto." 49

Broad-minded intellectuals, politicians and leaders of the churches protested against the gathering of the Jews. On 18 May, Áron Márton, the Roman Catholic bishop of Gyulafehérvár (today Alba-lulia), urged his parishioners in the Saint Michael parish church in Kolozsvár to protest against the limitation of the human rights: "No priest of Jesus Christ

48 Márton Varga, 10 November 2003.

49 Ferenc László, 11 November 2003. 
can refuse the charge of fighting for truth. He must see his brethren in every human being regardless of his or her religion or language.[...] You may suffer persecution; may be mocked at or have mud thrown at you; it is possible that your wages will be ingratitude instead of gratitude and appreciation. But prison or other people' opinion must not discourage us from fulfilling our duty, because we consider it a sacred task. It is not a shame but a glory to suffer persecution and detention for defending the truth and serving the law of love." 50

Thousands of people gathered around the Saint Michael church heard the sermon of Bishop Áron Márton through the loudspeakers. Four days later the ecclesiastical leader sent an appeal of protest to the authorities who had completed dragging away the Jews. He also wrote letters demanding an explanation from the Governors' Office of Kolozs County and from the Central Police Station of Kolozsvár in which he used harsh words. He sent the texts of his sermon from 18 May and of his letters to the authorities to the papal nuncio Angelo Rotta and to Jusztinián Serédi the Prince Primate of Hungary. After this, he wrote some other letters to the highest authorities: the Prime Minister Döme Sztójay, and Andor Jaross the Minister of the Interior. But his words demanding humanitarian behaviour as a duty of every Christian were completely ignored. On the contrary, he was declared persona non grata by the government of Hungary and expelled from the country. He had to go back to Alba lulia, then situated in Southern Transylvania, part of Romania. ${ }^{51}$

After only three weeks of functioning, the ghetto of Kolozsvár was emptied in two weeks by railway transports to Auschwitz. All of the Jews from Kolozs county were deported by six transports on 25, 27, 29, 31 May and on 5 and finally 7 June 1944. ${ }^{52}$ A lot of the deported Jews still believed that they would be transported into labour camps in the western part of Hungary. Beside the commanders of the ghetto, some Hungarian administrative authorities and members of the Gestapo also took part in the action of deportation. They were: Dr. Lajos Vargha, the Governor of Kolozs county, Dr. Ferenc Szász the Under-Sheriff of the county, Dr. László Vásárhelyi, the Mayor of Kolozsvár city, Dr. Géza Papp the Prefect of the police of Kolozsvár, and finally Dr. Strohschneider and Dr. Roeder as well, who were the commanders of the Gestapo in Kolozsvár. ${ }^{53}$

In the $20^{\text {th }}$ century history of Transylvania and Kolozsvár, the year 1944 brought the most important changes since the end of the First World War and the peace treaty of Trianon in 1919-1920. The events during the seven months between the German occupation in March and the Soviet invasion in October represented for the population of this region and its capital the terrifying reality of the biggest war in the history of mankind. These catastrophic events were: the mass arests of left wing sympathizers in April, the deportation of the Jews in May, the Allied bombardment on 2 June, the failure in September of a desperate attack of the $2^{\text {nd }}$ Hungarian Army against Romania to bring again South Transylvania under Hungarian rule, then the withdrawal of the German and Hungarian armies from Northern Transylvania in October, and finally "the glorious liberation" of the region by the Red Army

50 LŐWY, 258-259.

51 Ibidem, 124-125.

52 lbidem, 197.

53 Ibidem, 242-243. 
and its new Romanian ally. When the dust settled and the artifical division of Transylvania ended, the old, historical city of Kolozsvár regained its status as the cultural and administrative centre of the entire region, reflecting through its own history the dramatic conflicts and changes which took place in central Europe during the twentieth century.

\section{Abstract}

This year, there is the $70^{\text {th }}$ anniversary of the German occupation of Hungary. Therefore, with this study I would like to commemorate this very important historical event, which had decisive effects on the future of the Hungarian state and society as well. Naturally, until nowadays there have appeared a lot of books, studies and scientific articles which present the occupation, but most of them deal with the problem in general, referring to the whole country.

In order to complete the general scene, in my study I focused only on the capital of the Northern Transylvanian region, reincorporated to the Hungarian Kingdom in 1940. The city of Kolozsvár (today, officially in Romanian language: Cluj-Napoca) was the administrative and cultural center of the eastern part of Hungary in that time, therefore it shows very well the exact consequences of the occupation. First of all, I shortly presented the political and military conditions of the German invasion of the country, and after that, the occupation process of Kolozsvár. For a better description of the entering of Wehrmacht troops in the city, I used some interviews made to persons who were eye-witnesses to the events. Beside these, I obtained a lot of data from the local contemporary Hungarian and Romanian press, and several scientific publications and articles published recently.

The main objective of this study is to realize an analysis of exact consequences of the German occupation of Kolozsvár in 1944 upon the population of the city, and especially upon the Jewish community. Through the description of the mass arrests of left wing sympathizers, and the collection of the Jews in ghettos, as well as the deportation process, I tried to present one of the most dramatic period of the old, historical city of Kolozsvár.

\section{Keywords}

German troops, invasion, occupation, Gestapo, Jews, concentration, ghetto, deportation, Holocaust, citizens, indignation, fear

\section{References}

Ellenzék, 1944, Year 65, No. 67.

Keleti Újság, 1944, Year 27, No. 84

Keleti Újság, 1944, Year 27, No. 118.

Tribuna Ardealului, 1944, Year 5, No. 1004.

Ferenc László, interview by author, tape recording, Kolozsvár, 11 November 2003.

Sándor Dózsa, interview by author, tape recording, Kolozsvár, 6 November 2003.

Márton Varga, interview by author, tape recording, Kolozsvár, 10 November 2003.

ABLONCZY, Balázs: A visszatért Erdély 1940-1944, Budapest 2011. 
BETHLEN, Béla: Észak-Erdély kormánybiztosa voltam, Budapest 1989.

BRAHAM, Randolph L.: A magyar Holocaust, vol. 2, Budapest 1988.

CSATÁRI, Dániel: Forgószélben. Magyar-román viszony 1940-1945, Budapest 1968.

FINKELSTEIN, Arnold David: Fénysugár a borzalmak éjszakáján, Tel Aviv 1958.

GAAL, György: Kolozsvár kétezer esztendeje dátumokban, Kolozsvár 2001.

GOSZTONYI, Péter: A magyar honvédség a második világháborúban, Budapest 1995.

GOSZTONYI, Péter: Légiveszély, Budapest! Szemelvények Magyarország második világháborús történetéből (1939-1945), Budapest 1989.

KÁLLAY, Miklós: Magyarország miniszterelnöke voltam 1942-1944, vol. 2, Budapest 2012.

LŐWY, Dániel: A téglagyártól a tehervonatig. Kolozsvár zsidó lakosságának története, Kolozsvár 1998.

MURÁDIN, Kristóf János: Összmagyar gondolat regionális köntösben. Az Erdélyi Párt története 1940 és 1944 között, in: Trianoni Szemle, 5, 2013, 1-2, 79.

ORMOS, Mária: Magyarország a két világháború korában (1914-1945), Debrecen 1998.

ÖRVENDI, Ignác: Magyarország német megszállása, Budapest 1993.

RÁNKI, György: Unternehmen Margarethe: Die deutsche Besetzung Ungarns, Budapest 1984.

ROMSICS, Ignác: Magyarország története a XX. században, Budapest 2003.

SCHRAMM, Percy Ernst: Kriegstagebuch des Oberkommando des Wehrmacht (Wehrmachtführungsstab) 1940-1945, vol. 4, Frankfurt am Main 1965.

ŞORBAN, Raoul: Remember. 40 de ani de la masacrarea evreilor din Ardealul de Nord sub ocupația horthystă, Bucharest 1985.

THIRRING, Lajos: A visszacsatolt keleti terület. Terület és népesség, in: Magyar Statisztikai Szemle, 1940, 663.

VÁGÓ, Béla: Political and Diplomatic Activities for the Rescue of the Jews of Northern Transylvania, in: Yad Vashem Studies 6, 1967, 155.

VARGYAI, Gyula: Magyarország a második világháborúban, Budapest 2001.

WEINBERGER, Moshe Carmilly: A zsidóság története Erdélyben (1623-1944), Budapest 1995. 